https://doi.org/10.48009/2_iis_2005_204-209

\title{
IMPACT OF ECONOMIC PROSPERITY AND POPULATION ON E-GOVERNMENT INVOLVEMENT
}

\author{
Victor O. Wilkinson, Central Michigan University, wilki1vo@cmich.edu \\ James. J. Cappel, Central Michigan University, cappe1jj@ cmich.edu
}

\begin{abstract}
The Internet has attracted businesses and users to a medium where transactions and information exchange can be conducted anytime day or night. Like businesses, various levels of government have expanded their online presence over time. However, as the data of this study suggests, there remains significant variation in the extent to which county governments deliver Internet-based services and information to their citizens. This study utilized content and correlation analysis to determine whether the variables of economic prosperity and population had any significant effect on predicting the extent of county e-government involvement. The results indicated a positive correlation between the predictor variables and e-government involvement. Some implications and directions for future research are examined.
\end{abstract}

Keywords: E-government, website evaluation, content analysis, correlation study

\section{INTRODUCTION}

While e-government has been defined in different ways [4], most definitions have emphasized the online delivery of services by governments to their constituents [16]. For example, according to Deloitte Research, e-government is "the use of technology to enhance the access to and delivery of government services to benefit citizens, business partners, and employees" [4, p. 3]. Accordingly, "e-government involvement" is defined in this study as the extent to which governmental units (county governments) offer services to the public via their websites. The extent of these services can range from providing no service (i.e., having no website) to information dissemination, form download, online transactions, and other capabilities.

E-government offers a number of important advantages to both governmental units and the public. Government may use a website as a means of reducing paperwork, speeding up processes, and saving money. For example, when information on a site is clearly indexed and explained, the number of support calls is dramatically reduced [14]. The delivery of online services also helps governmental bodies meet the goals of the Government Paperwork Reduction Act, which aims at lowering the amount of paperwork handled by employees $[3,10]$.

The public also benefits by having a greater disposal of information "at its fingertips" via the web. To consumers, e-government provides quicker access to information, convenience, and a reduced need for phone calls or personal visits to governmental offices [6]. In this way, egovernment has the potential to bring citizens "closer" and "feel more connected to" their government $[1,7]$.

Based on these advantages, ideally, all government units would offer a wide array of web services to their constituents. However, some have observed that government has lagged behind 
their private sector counterparts in the use of the web [5]. Among different levels of government, it might be expected that smaller units such as county governments would exhibit more variation in their level of e-government than states or federal agencies that have more resources. This study explores the extent to which county governments provide services to their constituents over the web, and it examines whether the income and population of a county have a significant relationship to counties' level of e-government involvement.

\section{LITERATURE REVIEW}

Content analysis has been a commonly used research technique to assess organizations' website strategies and content, and development practices. Liu et al. [9] studied the content of company home pages and Liu and Arnett [8] compared companies' website privacy policies. Campbell and Beck [2] used content analysis to assess organizational responses on their websites to public allegations of ethical malpractice. Singh et al. [13] compared the Chinese and domestic versions of selected Fortune 500 company websites. Zhao and Zhao [17] looked at Internet technologies used by a sample of INC. 500 companies.

As McCarty and Aronson [11] noted, websites differ markedly in terms of their capabilities. They proposed a four level framework for website classification: 1. introductory (identifying products and services); 2. informative (directing customers to specific locations to complete their transactions); 3. interactive (being able to purchase goods online) and 4. intelligent (personalizing websites to meet customer's specific needs). Most previous content analysis website studies have considered the websites of large companies; few studies have addressed governmental websites, particularly at the county level. One small scale study of the websites of seven counties in Michigan found significant variability in website capabilities between counties, and that these government entities seemed to lag behind private companies; in 2001, six of these seven counties did not allow online payment at their website and in the other county it was in the development stage [12].

In speaking about private sector companies, Liu and Arnett [8] observed that "The Fortune 500 represents traditional leadership in the use of technologies and business practices." In other words, because these companies are larger and have more resources than other firms, they would be expected to assume a leadership role in the use of information technology. Extending this logic to county governments in the public sector, it might be expected that those counties who are biggest and have the most resources would be more advanced in terms of their website capabilities. In other words, those counties with greater average household incomes and population might be expected to have a greater level of e-government involvement. However, based on a literature review, no prior studies were encountered by the authors that tested these propositions. Accordingly, this study will consider two hypotheses, stated in null form, below:

$\mathrm{H}_{1}$ : There is no relationship between economic prosperity and e-government involvement.

$\mathrm{H}_{2}$ : There is no relationship between population and e-government involvement. 


\section{METHODOLOGY}

This study is based on a stratified random sample of counties in Michigan. The state's 83 counties were listed in descending order based on median household income and then divided into approximately four equal strata (groups) on this basis. The first group consisted of those counties with the highest median household income, followed by the second group which had the second highest median household income, and so on. Eight counties were randomly selected from each stratum, so that the total number of counties considered in this investigation was 32 . Population and income data for the counties were obtained using the latest publicly available information at the United States Census website; population data is from the most recent 2000 U.S. census and the income data is for 1999.

County websites were located using the state of Michigan's website, which contained links to most county websites. If the site of a certain county did not have a link, it was searched for using search engines such as Google. The website of each county included in the sample was examined using content analysis to determine its level of e-government involvement. Each website was assigned an "e-government score" using the following scale: 1 if a county had no website; 2 if the county had a website and it provided information or links to its various county offices; 3 if the county website provided users the ability to download forms; and 4 if the county's website provided interactive capabilities such as the ability to pay bills online, renew services, or look up property tax information. Thus, the more advanced website capabilities provided, the higher the score. The detailed data collected for this study is presented in Table 1.

\section{FINDINGS}

As shown in Table 1, the counties in the sample showed considerable variation with respect to the extent they delivered services and information via the web. Twenty-five percent (8 of 32) counties had no website, and nine other counties used their websites for information dissemination, i.e., receiving an e-government score of 2. Seven counties provided form download capabilities, and eight other counties provided interactive capabilities such as the ability to pay bills online.

The results of the correlation analysis are presented in Table 2. As indicated, a significant positive correlation was found between economic prosperity and e-government involvement as well as between population and e-government involvement. Thus, both of the null hypotheses presented earlier are rejected. In other words, the larger counties were in terms of median income and population, the greater their e-government involvement tended to be. 
Table 1. Income, Population, and E-Government Involvement

\begin{tabular}{|c|c|c|c|}
\hline County & Median Income & Population & E-Govt. Score \\
\hline Barry & 46820 & 56755 & 4 \\
\hline Calhoun & 38918 & 137985 & 4 \\
\hline Emmet & 40222 & 31437 & 4 \\
\hline Genesee & 41951 & 436141 & 4 \\
\hline Grand Traverse & 43169 & 77654 & 4 \\
\hline Jackson & 43171 & 158422 & 4 \\
\hline Kent & 45980 & 574335 & 4 \\
\hline Oakland & 61907 & 1194156 & 4 \\
\hline Berrien & 38567 & 162453 & 3 \\
\hline Clare & 28845 & 31252 & 3 \\
\hline Eaton & 49588 & 103655 & 3 \\
\hline Leelanau & 47062 & 21119 & 3 \\
\hline Roscommon & 30029 & 25469 & 3 \\
\hline St. Joseph & 40355 & 62422 & 3 \\
\hline Van Buren & 39365 & 76263 & 3 \\
\hline Alpena & 34177 & 31314 & 2 \\
\hline Charlevoix & 39788 & 26090 & 2 \\
\hline Crawford & 33364 & 14273 & 2 \\
\hline Hillsdale & 40396 & 46527 & 2 \\
\hline Lapeer & 51717 & 87904 & 2 \\
\hline Manistee & 34208 & 24527 & 2 \\
\hline Osceola & 34102 & 23197 & 2 \\
\hline Schoolcraft & 31140 & 8903 & 2 \\
\hline Wexford & 35363 & 30484 & 2 \\
\hline Alger & 35892 & 9862 & 1 \\
\hline Delta & 35511 & 38520 & 1 \\
\hline Lake & 26622 & 11333 & 1 \\
\hline Luce & 32031 & 7024 & 1 \\
\hline Mackinac & 33356 & 11943 & 1 \\
\hline Mason & 34704 & 28274 & 1 \\
\hline Missaukee & 35224 & 14478 & 1 \\
\hline Oscoda & 28228 & 9418 & 1 \\
\hline
\end{tabular}

Table 2. Correlation Results

$\begin{array}{llll}\text { Correlation: } & \text { r } & \text { p }\end{array}$

\begin{tabular}{lll}
\hline Economic Prosperity with E-Government Involvement & .60 & $.000 * * *$
\end{tabular}

$\begin{array}{lll}\text { Population with E-Government Involvement } & .49 & .004 *\end{array}$

$* \mathrm{p}<.05 ; * * \mathrm{p}<.01 ; * * * \mathrm{p}<.001$ 


\section{CONCLUSIONS}

As these results suggest, there remains significant variation in the extent to which governmental bodies, particularly county governments, are utilizing the web to deliver services to their residents. While web technologies have been well established for years, some county governments do not yet have a website, while other counties' websites are limited to more basic functions such as information dissemination. This raises a concern whether county governments are harnessing the power of the web as much as they should be to serve their constituents.

There are a number of factors that may help to explain the variation of county government websites. This investigation considered two of those factors, income and population, and found that a significant correlation exists between each of these factors and e-government involvement. Thus, the level of resources and size of a county appears to be associated with the extent to which it delivers services via the web - meaning the larger a county is in terms of income and population, the greater its e-government involvement.

It should be emphasized that this is an exploratory study based on a limited sample size of counties drawn from one state. Thus, its findings may not apply to other states. It should also be stressed that while the data are fairly current (collected in late 2004), they are nonetheless crosssectional, i.e., collected at one point in time. It is possible that counties will expand their online presence and delivery of services in the future, and that follow-up studies could obtain somewhat different results. However, this study presents an interesting benchmark of where a random sample of Michigan counties was in terms of their e-government involvement in late 2004. Lastly, since this is a correlation study, the findings do not demonstrate causality, i.e., that lower population levels and income of a county cause it to have less e-government involvement. Instead, the results indicate an association between the predictor and criterion variables.

Since research in this domain is relatively new, follow-up studies are encouraged to provide a greater understanding of those factors that influence e-government involvement. Additional studies could consider: other predictors besides income and population; the websites of other levels of government (e.g., states, cities, or townships); county government sites in other states or across the nation; or the use of other website (e-government) metrics.

This research may generate additional insight to help public administrators develop and manage their websites. For example, if the findings of additional studies suggest that the extent of egovernment involvement is, in part, a resource issue, state law makers might initiate efforts to share knowledge across counties or provide supplemental funding to smaller, less populated counties to improve their online delivery of services. These are public policy decisions that are the domain of law makers. Additional research may provide lawmakers with the ability to make more informed decisions on these issues so constituents can be better served. 


\section{REFERENCES}

1. Bowser, B. (1998). www.localgovernment.com: Opening the Window to On-line Democracy, The American City \& County, (6), 32-38.

2. Campbell, D. \& Beck, A. C. (2004). Answering Allegations: The Use of the Corporate Website for Restorative Ethical and Social Disclosure, Business Ethics, 13(2), 100.

3. Frock, J. (2001). Wooing Uncle Sam for E-gov Business, B To B Chicago, 86(10), 13.

4. Grant, G. \& Chau, D. (2005). Developing a Generic Framework for E-Government, Journal of Global Information Management, 13(1), 1-30.

5. Isaacs, L. (2002). Setting the Federal E-government Agenda, The American City \& County, (2), 63-65.

6. Isaacs, L. (2001). The World at Your Fingertips, The American City \& County, (2), 32-34.

7. Kersten, G. (2003). E-democracy and Participatory Decision Processes: Lesions from Enegotiation Experiments, Journal of Multicriteria Decision Analysis, (17), 127-144.

8. Liu, C. \& Arnett, K. P. (2002). An Examination of Privacy Policies in Fortune 500 Web Sites, Mid-American Journal of Business, 17(1), 13-21.

9. Liu, C., Arnett, K. P., Capella, L \& Beatty, R. (1997). Web Sites of the Fortune 500 Companies: Facing Customers through Home Pages, Information \& Management, 31(6), 335-446.

10. Mattly, J. (2000). Thirty years of Progress - in Less than a Year, AFP Exchange, 4(6), 10.

11. McCarty, R. V. \& Aronson, J. E. (2000-2001). Activating Consumer Response: A Model for Web Site Design Strategy, Journal of Computer Information Systems (Winter), 2-7.

12. Rocha, M. (2001). Government Crawls on the Web, Saginaw News (Feb. 4): B1, B3.

13. 13. Singh, N., Zhao, H., \& Hu, X. (2003). Cultural Adoption on the Web: A Study of American Companies' Domestic and Chinese Websites, Journal of Global Information Management, 11(3), 63-80.

14. TechWeb website. e-government, Available at: www.techweb.com, Accessed January 25, 2005.

15. U.S. Census Bureau, Michigan Quickfacts, Available at http://quickfacts.census.gov/qfd/states/26000.html, Accessed January 18, 2005.

16. Wikipedia website. EGovernment, Available at: www.wikipedia.org, Accessed January 25, 2005.

17. Zhao, J. J. \& Zhao, S. Y. (2004). Internet Technologies Used by IC. 500 Corporate Web Sites, Issues in Information Systems, (4), 366-372. 